\title{
ARE LEVERAGE AND DEBT MATURITY COMPLEMENTS OR SUBSTITUTES? EVIDENCE FROM LATIN AMERICA
}

\section{A ALAVANCAGEM E A MATURIDADE DO ENDIVIDAMENTO SÃO COMPLEMENTARES OU SUBSTITUTOS? EVIDÊNCIA DA AMÉRICA LATINA}

PAULO RENATO SOARES TERRA

Doutor em Administração, McGill University, Canadá. Professor adjunto de Finanças do Programa de Pós-Graduação em Administração da Universidade Federal do Rio Grande do Sul (UFRGS). Rua Washington Luís, 855, sala 321 - Porto Alegre - RS - Brasil - CEP 90010-460

E-mail: prsterra@ea.ufrgs.br 


\section{ABSTRACT}

The aim of this paper is to investigate the choice between debt and equity simultaneously with the decision between short- and long-term debt for a large sample of emerging markets from Latin America. In order to do this, we test a model (BARCLAY; MARX; SMITH JR., 2003) of joint capital structure and debt maturity determination for a sample of 986 firms from Latin America in the period I9902002, employing the Generalized Method of Moments on a system of equations. The empirical results support three main findings. First, capital structure and debt maturity are financial policy complements in Latin America. Second, there is a substantial dynamic component in the determination of debt maturity that has been neglected by previous research. Finally, firms face moderate adjustment costs towards their optimal maturity. Results are robust to variation in sample composition in terms or countries, industries, and years.

\section{KEYWORDS}

Capital structure; Debt maturity; Trade-off, Dynamic panel data analysis; Latin America.

\section{RESUMO}

O objetivo deste artigo é investigar a decisão entre dívida e capital próprio simultaneamente com a decisão entre endividamento de curto e longo prazos para uma grande amostra de mercados emergentes da América Latina. Para tanto, testa-se um modelo (BARCLAY; MARX; SMITH JR., 2003) de determinação conjunta da estrutura de capital e da maturidade do endividamento para uma amostra de 986 empresas da América Latina no período 1990-2002, empregando-se o método dos momentos generalizados num sistema de equações. Os resultados empíricos apoiam três resultados principais. Primeiro, o grau de endividamento e a sua maturidade são políticas financeiras complementares na América Latina. Segun- 
do, há um componente dinâmico substancial na determinação da maturidade do endividamento que tem sido negligenciado por pesquisas anteriores. Finalmente, as empresas enfrentam moderados custos de ajuste em direção à sua maturidade ótima de endividamento. Os resultados são robustos à variação na composição da amostra em termos de países, setores e anos.

\section{PALAVRAS-CHAVE}

Estrutura de capital; Maturidade da dívida; Trade-off; Análise dinâmica de dados em painel; América Latina.

\section{INTRODUCTION}

Since the breakthrough work of Modigliani and Miller (1958, henceforth $\mathrm{MM}$ ) on capital structure, corporate financial theory has furthered our understanding of a range of financial decisions: the choice between debt and equity, the design of a payout policy, the use of convertible instruments, and the management of financial risks, among others. In their influential paper and the ones that followed (MILLER; MODIGLIANI, I96I; MODIGLIANI; MILLER, I963; MILLER, I977), these authors laid down the conditions under which the firm would be largely indifferent to the sources of its financing. In the fifty years that followed the publication of their work, several papers have explored both theoretically and empirically the implications of their famous Propositions I, II and III. Capital structure and dividend policy are perhaps the most studied issues in corporate finance. Much less attention however has been devoted to the maturity structure of the firm's financing. Moreover, most of the theoretical and empirical work so far has focused on a single decision at a time. That is, each financial decision is taken as independent of the other decisions. It may be the case that some of these decisions are not independent but actually complements or substitutes among each other. If that is the case, we must investigate whether there is interdependence among them or not.

This paper contributes to the existing body of knowledge in several ways. First, we test the Barclay, Marx, and Smith Jr.'s (2003) model of joint capital structure and debt maturity determination in a multi-country framework, in an attempt to understand country-specific differences. We focus on a sample of developing countries that have so far been ignored in empirical studies. To our knowledge, this is the first attempt in the literature to investigate such problem in a multi-country emerging market sample. Moreover, we do so by employing 
empirical techniques that account properly for cross-section and time series variation. Also, we model dynamic effects that have not been considered in the original research.

Our main findings suggest that there is a substantial dynamic component in the determination of a firm's maturity structure, which has been ignored by previous research. Moreover, our results suggest that capital structure and debt maturity are policy complements in Latin America, an empirical finding that contradicts Barclay, Marx, and Smith Jr.'s (2003) theoretical prediction. The study also finds that firms face moderate adjustment costs towards its optimal policies.

The remaining of the paper is organized as follow: the next section lays down the theoretical underpinnings of the joint capital structure/debt maturity decision. Section 3 presents the data sources, the variables, the model, describes the sample, and the empirical techniques. Section 4 presents and discusses the findings. The last section summarizes the results and concludes the paper.

\section{THEORETICAL FRAMEWORK AND PREVIOUS EMPIRICAL EVIDENCE}

Theoretical explanations for the choice of corporate debt maturity are already implied in MM's original paper, but are eventually formalized by Stiglitz (I974). MM's paper does not consider a multi-period setting, and Stiglitz (I974) provides a rigorous analysis of their model in such circumstances. His conclusions are that, under a fairly general set of conditions (absence of taxation, transaction costs, bankruptcy costs, and other market frictions) the maturity choice of the firm is irrelevant, just as MM's findings regarding the firm's leverage ratio under the same conditions. Of course, once one departs from the ideal world of the financial economists ${ }^{\mathrm{I}}$, such frictions matter, and therefore the maturity decision would influence the firm's valuation just as would the set of other financial policies. A large family of hypotheses explores the tax-based, bankruptcy costs, and transaction costs approaches in order to offer an explanation for the maturity choice.

Barclay, Marx, and Smith Jr. (2003) propose the requirements for a theory of financial policy to have testable implications. The authors focus their work on the choice between leverage and maturity. They develop their model from the argument that a firm chooses leverage and debt maturity to maximize its value given a set of exogenous firm characteristics such as its investment opportunity 
set and regulatory status. In order to obtain unambiguous predictions in reduced form equations, the value functions must have monotone comparative statics, which is guaranteed only if particular properties are satisfied (single-crossing and quasi-supermodularity).

The term "single crossing" is used because the objective function crosses zero only once (and only from below) when this condition holds (MILGROM; SHANNON, 1994). Milgrom and Shannon (I994) remark that not only is the single crossing property a condition describing the relationship between the choice variables and the parameters, but it is also an ordinal condition. Simply put, "the single crossing property says that, if a given increase in the decision variable is profitable when the parameter is low, the same increase will continue to be profitable when the parameter is high" (AMIR, 2005, p. 636). Moreover,

[...] quasi-supermodularity expresses a weak kind of complementarity between the choice variables; if an increase in some subset of the choice variables is desirable at some level of the remaining choice variables, it will remain desirable as the remaining variables also increase (MILGROM; SHANNON, I994, p. I62).

Thus, single crossing is a weaker property than quasi-supermodularity. Barclay, Marx, and Smith Jr. (2003) show that, for the leverage-maturity problem, the single crossing property holds, but the quasi-supermodularity one does not. The practical implication is that leverage and debt maturity are likely to be substitute policies instead of complementary ones. Complementarity can be defined as mutually reinforcing increases in the case of multiple endogenous variables (AMIR, 2005), while substitutability can be defined as increases in one of the endogenous variables replaces increases in other endogenous variables. In other words, firms facing restrictions in their level of leverage (e.g. borrowing restrictions) may make up for it by extending the maturity of their debt and vice-versa.

Barclay, Marx, and Smith Jr. (2003) illustrate their point empirically using data from 5,765 industrial firms in the United States from I980 to I999. Besides endogenous variables for capital structure and debt maturity, the authors employ exogenous variables such as growth opportunities, industry regulation, firm size, profitability, tangibility, asset maturity, average tax rate, net-operating loss carryforwards, and a dummy variable for firms with commercial paper programs. Their empirical analysis suggests that capital structure and debt maturity are substitutes in addressing financial problems of the firms although the authors have faced several difficulties in correctly identifying the leverage equation.

Even though capital structure is one of the most scrutinized subjects in the finance literature, fewer studies investigate debt maturity - even less so in an 
international setting. Antoniou, Guney, and Paudyal (2006) study the determinants of debt maturity for a sample of 358 French, 582 German, and 2,423 British non-financial firms and find that debt maturity depends on both firm-specific and country-specific factors, opening the question of the degree of influence of each group of factors on the maturity structure. Larger sets of countries are studied by Demirgüç-Kunt and Maksimovic (I999) who explored the hypothesis that the financial development of a country determines the maturity of its firms' debt. The authors investigate 9,649 non-financial firms from 30 countries including developing ones in the period I980-I991. They find support for the hypothesis that legal and institutional differences among countries explain a large part of the leverage and debt maturity choices of firms. Fan, Titman, and Twite (2008) also study the subject for II industries in 39 countries in the period I991-2006. Their results largely support Demirgüç-Kunt and Maksimovic (I999) findings.

To the best of our knowledge, so far, the only study that focused specifically on developing countries is Erol (2004), who analyzed the strategic content of debt maturity in a sample of 15 manufacturing sectors from Turkey during the period I990-2000. The author's findings are that long-term debt is strategic while short-term debt, despite being devoid of strategic content, is associated with financial constraint. Erol (2004), however, limits his analysis to a single emerging market.

Besides most of previous empirical studies having neglected multi-country emerging markets samples, one criticism that may be raised against Barclay, Marx, and Smith Jr.'s (2003) paper is that it ignores the effect that lagged leverage and maturity may have on the determination of the contemporaneous endogenous variables. As a matter of fact, it is likely that the change in a firm's capital structure and debt maturity is somewhat rigid and by no means costless. If that is the case, the previous period's level of debt and maturity is a relevant variable in the firm's choice today. These are particular aspects that we intend to improve in the empirical analysis that follows. In the next section, we describe the methods, variables, and data we employ in order to investigate the joint capital structure debt maturity decision of non-financial firms in the seven biggest economies of Latin America.

\section{DATA, VARIABLES, MODEL, AND EMPIRICAL METHODS}

\subsection{DATA AND VARIABLES}

Our choice of countries for this study focused in emerging markets that have gone through substantial structural changes in the past couple of decades. Latin 
America has experienced hyperinflation and economic instability over the I980s and profound economic reforms in the I990s, including extensive privatization programs.

The primary data sources are from the Economática Pro $^{\odot}$ database for Latin American countries (ECONOMÁTICA, 2003). Only listed firms are included in the sample. Observations are yearly during the period I990-2002 the level of analysis is each firm. The database contains I,242 firms over the period covered. Firms from the financial industry were excluded as well as firms with missing data for key variables. Thus, the final sample contains 986 firms and I3,490 observations from Latin America. In order to reduce the survival bias, firms are allowed to leave and enter the dataset over time. Firms are classified in Ig industry sectors, according to their primary NAICS codes. Panel A of Table I presents the distribution of firms and observations by country. We highlight the share of Brazilian firms in the sample, making up more than $40 \%$ of the firms and slightly less of the observations. In the other extreme is Venezuela, with only 28 firms in the sample and less than $3 \%$ of the observations.

\section{TABLE I}

\section{SUMMARY STATISTICS FOR ENDOGENOUS VARIABLES}

\begin{tabular}{lcc}
\hline & PANEL A: FIRMS BY COUNTRY & \\
\hline COUNTRIES & FIRMS & $\%$ \\
\hline Argentina & 76 & 7.7 \\
\hline Brazil & 395 & 40.1 \\
\hline Chile & 169 & 17.1 \\
\hline Colombia & 47 & 4.8 \\
\hline Mexico & 145 & 14.7 \\
\hline Peru & 126 & 12.8 \\
\hline Venezuela & 28 & 2.8 \\
\hline Latin America & 986 & 100.0 \\
\hline
\end{tabular}


TABLE I (CONTINUATION)

SUMMARY STATISTICS FOR ENDOGENOUS VARIABLES

\begin{tabular}{lccc|ccc}
\hline \multicolumn{7}{c}{ PANEL B: DESCRIPTIVE STATISTICS BY COUNTRY } \\
\hline \multirow{2}{*}{ COUNTRIES } & \multicolumn{7}{c}{ LEVERAGE } & \multicolumn{3}{c}{ MATURITY } \\
\cline { 2 - 8 } & OBS. & MEAN & STD. DEV. & OBS. & MEAN & STD. DEV. \\
\hline Argentina & 614 & 0.9552 & 6.7349 & 538 & 0.4184 & 0.3283 \\
\hline Brazil & 3270 & 1.6999 & 15.1451 & 2850 & 0.4645 & 0.3078 \\
\hline Chile & 1742 & 0.3266 & 0.6098 & 1518 & 0.4997 & 0.3540 \\
\hline Colombia & 280 & 0.4687 & 1.7781 & 241 & 0.4617 & 0.3410 \\
\hline Mexico & 1324 & 0.6869 & 1.2427 & 1204 & 0.5431 & 0.3227 \\
\hline Peru & 1012 & 1.0447 & 19.5014 & 142 & 0.4012 & 0.3392 \\
\hline Venezuela & 175 & 0.2757 & 0.3367 & 146 & 0.4292 & 0.3112 \\
\hline Latin America & $\mathbf{8 4 1 7}$ & $\mathbf{1 . 0 5 2 7}$ & $\mathbf{1 1 . 7 8 2 6}$ & $\mathbf{6 6 3 9}$ & $\mathbf{0 . 4 8 0 8}$ & $\mathbf{0 . 3 2 7 2}$ \\
\hline
\end{tabular}

"The sample consists of I3,490 observations for firms of Argentina, Brazil, Chile, Colombia, Mexico, Peru and Venezuela (ECONOMÁTICA, 2003) over the period I990-2002. Leverage is calculated as the book value of long-term debt over book value of equity. Maturity is the book value of long-term financial debt over book value of short-term loans plus book value of long-term financial debt. "Latin America" refers to the pooling together of all firm-level data for Argentina, Brazil, Chile, Colombia, Mexico, Peru, and Venezuela.

Source: Elaborated by the author.

The endogenous variables are proxies of the leverage and maturity of debt carried by each firm measured as follows: Long-Term Book Debt over Book Equity, i.e., the debt-to-equity ratio ("Leverage"), and Long-Term Financial Debt over Short-Term Loans plus Long-Term Financial Debt ("Maturity").

Panel B of Table I shows the summary statistics for Leverage and Maturity variables, respectively. Brazil has the most leveraged firms in average, while Venezuelan firms are the least indebted ones in the sample. The high variation of the debt-to-equity ratios of Peruvian firms stands out. Maturities, on the other hand, are much more homogeneous both within and across countries. Mexico presents firms with longer debt maturities while Peru has the shortest ones.

Firm-specific determinant factors for the debt maturity structure are chosen from those often suggested in the literature. The set of firm-specific explanatory variables consists of the following: size, growth opportunities, profitability, business risk, liquidity, tangibility, tax effects, and a dummy variable to control for regulated industries. The measurement of such variables is presented in Picture I, and it is standard in the extant literature. 
PICTURE I

DEFINITION OF EXOGENOUS VARIABLES*

\begin{tabular}{lc}
\hline VARIABLE & DEFINITION \\
\hline Size & Natural Logarithm of Sales \\
\hline Growth Opportunities & (Book Liabilities + Market Capitalization) $\div$ Total Book Assets \\
\hline Profitability & Operating Income $\div$ Total Book Assets \\
\hline Business Risk & Sales $\div$ Operating Income \\
\hline Liquidity & Current Assets $\div$ Current Liabilities \\
\hline Tangibility & Net Fixed Assets $\div$ Total Book Assets \\
\hline Tax Effects & Taxes Due $\div$ Earnings Before Taxes \\
\hline Regulation Dummy & Gas and Oil, Mining, Telecommunications, and Transport and \\
& Logistics, and zero otherwise \\
\hline
\end{tabular}

"Exogenous variables are computed based in accounting and stock market data provided by the Economática Pro ${ }^{\odot}$ database (2003) over the period 1990-2002.

Source: Elaborated by the author.

Table 2 reports summary statistics for the exogenous variables of Latin American firms. Inspecting the table, we can conclude that Argentine firms are the most profitable and have the lower risk ${ }^{2}$ but are the least liquid; Brazilian firms are the most heavily taxed of the continent; Chilean firms are the most valuable in the market; Colombia have the riskier and the least profitable firms, and those with less tangible assets; Mexican firms are bigger and more liquid, but have the lowest average taxation; Peruvian firms are the smallest, Venezuela have firms with more tangible assets but the least valuable. Overall, standard deviations of such variables at the firm level are very high both within and across countries.

Finally, we also define a dummy variable to control for regulated industries. This variable assumes the value of $\mathrm{I}$ if the firm's main industrial activity belongs to one of the following industries: Construction, Electricity, Gas and Oil, Mining, Telecommunications, and Transport and Logistics. These industries are subject to closer government scrutiny even when pursued solely by private enterprises, and are submitted to stricter regulations than other activities.

2 Notice that our sample period ends in 2002, before the meltdown of the Argentine currency board regime and the ensuing economic crisis. 


\section{TABLE 2}

\section{SUMMARY STATISTICS FOR EXPLANATORY VARIABLES}

\begin{tabular}{|c|c|c|c|c|c|c|c|c|c|c|c|c|}
\hline \multirow{2}{*}{$\begin{array}{l}\text { COUNTRIES } \\
\text { VARIABLES }\end{array}$} & \multicolumn{3}{|c|}{ ARGENTINA } & \multicolumn{3}{|c|}{ BRAZIL } & \multicolumn{3}{|c|}{ CHILE } & \multicolumn{3}{|c|}{ COLOMBIA } \\
\hline & OBS. & MEAN & STD. DEV & OBS. & MEAN & STD. DEV & $O B S$. & MEAN & STD. DEV & OBS. & MEAN & STD. DEV \\
\hline Size & 582 & 11.3880 & 1.8235 & 2896 & 11.5804 & 1.8322 & 1580 & 10.2488 & 1.8960 & 297 & 11.0402 & 1.5650 \\
\hline $\begin{array}{l}\text { Growth } \\
\text { Opportunities }\end{array}$ & 497 & 0.9887 & 0.4354 & 2813 & 0.8115 & 0.4786 & 1320 & 2.1829 & 8.6707 & 201 & 0.8253 & 0.4274 \\
\hline Profitability & 614 & 0.3538 & 0.0711 & 3262 & 0.0308 & 0.8922 & 1748 & 0.05872 & 0.1025 & 287 & 0.0303 & 0.0781 \\
\hline Business Risk & 594 & 0.8755 & 155.6350 & 3253 & 1.2234 & 155.8223 & 1633 & 12.7145 & 125.3976 & 286 & 31.1815 & 725.7262 \\
\hline Liquidity & 614 & 1.6938 & 2.7358 & 3263 & 2.5267 & 22.5466 & 1738 & 5.0646 & 43.2245 & 281 & 1.6976 & 1.1712 \\
\hline Tangibility & 597 & 0.4597 & 0.2619 & 3265 & 0.3578 & 0.2621 & 1719 & 0.4111 & 0.2879 & 274 & 0.2494 & 0.1894 \\
\hline Tax Effects & 344 & 0.1399 & 1.0425 & 3260 & 0.4042 & 12.4357 & 1482 & 0.0295 & 0.8842 & 287 & 0.1107 & 1.5110 \\
\hline COUNTRIES & \multicolumn{3}{|c|}{ MEXICO } & \multicolumn{3}{|c|}{ PERU } & \multicolumn{3}{|c|}{ VENEZUELA } & \multicolumn{3}{|c|}{ LATIN AMERICA } \\
\hline VARIABLES & OBS. & MEAN & STD. DEV & OBS. & MEAN & STD. DEV & OBS. & MEAN & STD. DEV & OBS. & MEAN & STD. DEV \\
\hline Size & 1335 & 12.2981 & 1.7981 & 1005 & 10.2201 & 1.2713 & 166 & 10.9196 & 1.8189 & 7861 & 11.2121 & 1.9207 \\
\hline $\begin{array}{l}\text { Growth } \\
\text { Opportunities }\end{array}$ & 873 & 1.2778 & 0.6577 & 633 & 1.1085 & 0.7247 & 140 & 0.7463 & 0.3507 & 6477 & 1.1955 & 3.9775 \\
\hline Profitability & 1339 & 0.0756 & 0.7630 & 1010 & 0.0597 & 0.1178 & 175 & 0.0346 & 0.0659 & 8435 & 0.0475 & 0.0938 \\
\hline Business Risk & 1339 & 16.8693 & 196.8102 & 1006 & 14.8608 & 267.0739 & 171 & 2.1902 & 51.4443 & 8282 & 8.7048 & 218.0081 \\
\hline Liquidity & 1340 & 5.2687 & 99.4697 & 1012 & 2.0033 & 4.2355 & 175 & 2.1203 & 2.8290 & 8423 & 3.3263 & 46.4780 \\
\hline Tangibility & 1340 & 0.5120 & 0.2716 & 1012 & 0.4771 & 0.2220 & 175 & 0.5355 & 0.2263 & 8382 & 0.4152 & 0.2705 \\
\hline Tax Effects & 1339 & -4.1846 & 137.5319 & 1009 & 0.3121 & 3.9597 & 174 & 0.0971 & 1.5772 & 7895 & -0.4851 & 57.2277 \\
\hline
\end{tabular}

"The sample consists of I3,490 observations for firms of Argentina, Brazil, Chile, Colombia, Mexico, Peru and Venezuela (ECONOMÁTICA, 2003) over the period I990-2002. Size is the natural logarithm of sales. Growth Opportunities is equal as the book value of liabilities plus market capitalization over book value of total assets. Profitability is equal to operating income over book value of total assets. Business Risk is calculated as sales over operating income. Liquidity is book value of current assets over book value of current liabilities. Tangibility is defined as net fixed assets over book value of total assets. Tax Effects is equal to taxes due over earnings before taxes. "Latin America" refers to the pooling together of all firm-level data for Argentina, Brazil, Chile, Colombia, Mexico, Peru, and Venezuela.

Source: Elaborated by the author.

Table 3 presents the correlation matrix for the explanatory variables. Larger firms tend to be more profitable, with more growth opportunities, less liquidity, riskier and with more fixed assets as a proportion of total assets. Correlations are generally low in this sample (maximum of .2I and minimum of -..15), suggesting that the multi-collinearity problems among the explanatory variables should be negligible. 


\section{TABLE 3}

\section{CORRELATION MATRICES"}

\begin{tabular}{lccccccc}
\hline & SIZE & $\begin{array}{c}\text { GROWTH } \\
\text { OPPORTUNITIES }\end{array}$ & PROFITABILITY & $\begin{array}{c}\text { BUSINESS } \\
\text { RISK }\end{array}$ & LIQUIDITY & TANGIBILITY & $\begin{array}{c}\text { TAX } \\
\text { EFFECTS }\end{array}$ \\
\hline Size & 1.0000 & & & & & \\
\hline $\begin{array}{l}\text { Growth } \\
\text { Opportunities }\end{array}$ & 0.0696 & 1.0000 & & & & & \\
\hline Profitability & 0.2085 & 0.0233 & 1.0000 & & & & \\
\hline Business Risk & 0.0116 & -0.0016 & 0.0110 & 1.0000 & & \\
\hline Liquidity & $-0,0060$ & $-0,0243$ & -0.0177 & -0.1498 & 1.0000 & \\
\hline Tangibility & 0.1652 & 0.0568 & 0.1169 & 0.0070 & -0.0505 & 1.0000 & \\
\hline Tax Effects & -0.0200 & -0.0008 & 0.0039 & -0.0028 & 0.0003 & -0.0028 & 1.0000 \\
\hline
\end{tabular}

*The table presents the correlation matrix for firms in Latin America, and refers to the pooling together of all firm-level data for Argentina, Brazil, Chile, Colombia, Mexico, Peru, and Venezuela in the period $1990-2002$.

Source: Elaborated by the author.

\subsection{MODEL AND EMPIRICAL METHODS}

We specify the model as the following general (static) panel data model:

$$
\begin{aligned}
& \text { Leverage }_{i t}=\beta_{i}+\beta_{t}+\sum_{k=1}^{K} \beta_{k} Y_{i t}+\sum_{l=K+1}^{L} \beta_{l} Z_{i t}+\eta_{i}+\varepsilon_{i t} \\
& \text { Maturity }_{i t}=\gamma_{i}+\gamma_{t}+\sum_{k=1}^{K} \gamma_{k} Y_{i t}+\sum_{l=K+1}^{L} \gamma_{l} Z_{i t}+\omega_{i}+v_{i t}
\end{aligned}
$$

Where Leverage $_{i t}$ and Maturity ${ }_{i t}$ are the endogenous variables (the $i^{\text {th }}$-firm leverage and maturity ratios on the $t^{\text {th }}$-period), $Y_{i t}$ are the $K$ firm-specific explanatory variables, (including industry dummies in the simple pooling and randomeffects models), $Z_{i t}$ is the matrix of $L$ country dummies (in the simple pooling and random-effects models), $\beta_{i}$ and $\gamma_{i}$ are the firm-specific intercepts in the fixedeffects model, $\beta_{t}$ and $\gamma_{t}$ are period-specific intercepts, $\beta_{k}, \beta_{l}, \gamma_{k}$ and $\gamma_{l}$ are the exogenous variables coefficients to be estimated, $\eta_{i}$ and $\omega_{i}$ are the firm-specific error terms in the random-effects model, and $\varepsilon_{i t}$ and $v_{i t}$ are the error terms.

Preliminary runs of the fixed-effects model of Eq. I revealed a substantial presence of autocorrelation in the residuals. This finding raises the question 
that the debt policy of the firm may be dynamic, i.e., current leverage and maturity may depend on past leverage and maturity. Antoniou, Guney, and Paudyal (2006) explicitly model such possibility, and suggest that a dynamic rather than static panel data analysis may be more adequate. The next step then is to test then the lagged endogenous variable is added to Eq. I, which is then first-differenced yielding the dynamic system below:

$$
\begin{aligned}
& \Delta \text { Leverage }_{i t}=\beta_{0} \Delta \text { Leverage }_{i t-1}+\sum_{k=1}^{K} \beta_{k} \Delta Y_{i t}+\varepsilon_{i t} \\
& \Delta \text { Maturity }_{i t}=\gamma_{0} \Delta \text { Maturity }_{i t-1}+\sum_{k=1}^{K} \gamma_{k} \Delta Y_{i t}+v_{i t}
\end{aligned}
$$

Where $\beta_{\circ}$ and $\gamma_{\circ}$ are the endogenous variables coefficients to be estimated.

One advantage of this specification is that the rate of adjustment of the firm towards its optimal capital structure and maturity can be estimated respectively as $\lambda_{1}=\left(\mathrm{I}-\beta_{\mathrm{o}}\right)$ and $\lambda_{2}=\left(\mathrm{I}-\gamma_{\mathrm{o}}\right)$. If adjustment costs are high, the rate of adjustment is expected to be small ( $\lambda$ approaching zero), while a very high rate of adjustment ( $\lambda$ approaching one) suggests the presence of negligible adjustment costs.

Estimation of panel data models can be performed by Ordinary Least Squares in the case of simple pooling and fixed-effects formulations and by Generalized Least Squares for the random-effects formulation (HALL; CUMMINS, I997). However, in the presence of dynamic effects (lagged dependent variable amongst explanatory variables) OLS estimators are biased and inconsistent, and the same occurs with the GLS estimator (BALTAGI, I995). In order to overcome such problem, Anderson and Hsiao (I98I) suggest a first difference transformation to the model so that all variables constant through time for each cross-section unit are wiped out, including the fixed effects intercept. The authors estimate the transformed model with an Instrumental Variable approach. Advancing upon such approach, Arellano and Bond (I99I) suggest a two-step estimation procedure using GLS in the first step and then obtaining the optimal Generalized Method of Moments (GMM) estimator in the second step (HANSEN, I982). Such estimation is convenient because GMM does not require any particular distribution form, solving therefore problems of heteroskedasticity, normality, simultaneity, and measurement errors (ANTONIOU; GUNEY; PAUDYAL, 2006). Also, since GMM is an instrumental variable technique, that employs three-stage estimation in order to obtain the estimates, it is similar to the two-stage approach that Barclay, Marx, and Smith Jr. (2003) employed in their structural equation estimation. Therefore, in this paper we can also estimate the structural equations of leverage and maturity even though they may not have monotone comparative statics. 


\section{EMPIRICAL RESULTS}

\section{PRELIMINARY SPECIFICATION TESTS}

The first step is to determine whether the panel data specification that simply pools together all available data for all firms and time periods is adequate to describe the data 3 . As pointed out by Hsiao (I986), simple least squares estimation of pooled cross-section and time series data may be seriously biased ${ }^{4}$. The model tested in Eq. I includes firm-specific variables described above, as well as country-specific dummy variables. The results in Table 4 strongly reject the single intercept hypothesis.

\section{TABLE 4}

SPECIFICATION TESTS"

\begin{tabular}{cccc}
\hline \multicolumn{2}{c}{ PANEL A: F TEST } & \multicolumn{2}{c}{ PANEL B: HAUSMAN TEST } \\
\hline LEVERAGE & MATURITY & LEVERAGE & MATURITY \\
\hline F(714; 3908) & F(714; 3908) & $\chi^{2}(4)$ & $\chi^{2}(13)$ \\
\hline $2.0101 *$ & $4.9446 *$ & $101.960 *$ & 16.864 \\
\hline 0.000 & 0.000 & 0.000 & 0.206 \\
\hline
\end{tabular}

*PANEL A presents the F-Test of a Simple Pooled OLS against a Fixed-Effects Specification. This test statistic is for testing the null hypothesis that firms' intercepts in the basic fixed-effects panel data model are all equal, against the alternative hypothesis that each firm has its own (distinct) intercept. The test assumes identical slopes for all independent variables across all firms, and it is distributed $\mathrm{F}\left(\mathrm{df}_{\mathrm{I}}, \mathrm{df} 2\right)$. PANEL B presents the Hausman Specification Test of Random-Effects against Fixed-Effects Specification. This test statistic is for testing the null hypothesis of the random-effects specification against the alternative hypothesis of the fixed-effects specification in the basic panel data model, and it is distributed $\chi^{2}(\mathrm{df})$. The sample refers to the pooling together of all firm-level data for Argentina, Brazil, Chile, Colombia, Mexico, Peru, and Venezuela. Endogenous Variables: Leverage = Long-Term Book Liabilities $\div$ Book Equity; Maturity $=$ Long-Term Debt $\div$ Total Debt. $p$-values in italic.

* Significant at the I\% level.

Source: Elaborated by the author.

The next step is to determine which model of variable intercepts across firms better fits the data. Table 4 also presents the results for a Hausman specification test of random-versus fixed-effects. The test, as suggested by Hsiao (1986, p. 49), is

Such tests are not strictly required to implement the dynamic model, but they are reassuring in that the first differences model is indeed adequate.

4 Hsiao (I986, p. 6) refers to this as the "heterogeneity bias". 
particularly appropriate in situations where $N$ (the number of cross-sectional units) is large relative to $T$ (the number of time periods) - precisely the case of this study. Again, the model in Eq. I is employed. The test rejects the random-effects specification for the leverage equation but cannot reject it for the maturity equation.

Given these results, after first differencing Eq. I, firm-specific intercepts disappear. Random-effects, however, are not likely to disappear with differencing and are incorporated to the general error term in the dynamic model of Eq. 2 in the estimation that follows.

\subsection{DYNAMIC PANEL DATA ESTIMATION RESULTS}

As mentioned above, usual OLS and GLS estimators are biased and inconsistent when the lagged dependent variable is included in the right-hand side of the panel data model. In order to overcome this problem, GMM estimation is used instead.

The Eq. 2 is then estimated by Generalized Method of Moments (GMM) using as instruments first-order lagged values of the levels ${ }^{5}$ of explanatory variables, sector dummies, country dummies, and a constant. Standard errors are heteroskedasticity robust according to the method proposed by White (I980) ${ }^{6}$ and are also robust to autocorrelation. Results are reported in Table 5.

\section{TABLE 5}

PANEL DATA ANALYSIS OF MATURITY RATIOS FOR LATIN AMERICA*

\begin{tabular}{|c|c|c|c|c|}
\hline \multirow{4}{*}{ 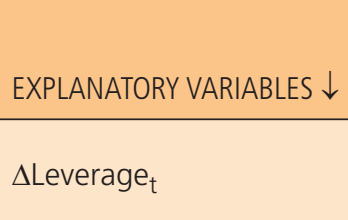 } & \multicolumn{4}{|c|}{ ENDOGENOUS VARIABLES } \\
\hline & \multicolumn{2}{|c|}{ LEVERAGE } & \multicolumn{2}{|c|}{ MATURITY } \\
\hline & & & 0.0262 & \\
\hline & & & 6.9861 & \\
\hline \multirow{2}{*}{$\Delta$ Maturity $_{\mathrm{t}}$} & 15.8237 & *** & & \\
\hline & 8.9450 & & & \\
\hline \multirow{2}{*}{$\Delta$ Leverage $_{\mathrm{t}-1}$} & 0.3281 & & -0.0039 & \\
\hline & 1.2109 & & -0.6735 & \\
\hline \multirow{2}{*}{$\Delta$ Maturity $_{\mathrm{t}-1}$} & -5.8078 & $* * *$ & 0.3679 & *** \\
\hline & -6.0183 & & 8.8230 & \\
\hline
\end{tabular}

(continue) 


\section{TABLE 5 (CONTINUATION)}

PANEL DATA ANALYSIS OF MATURITY RATIOS FOR LATIN AMERICA*

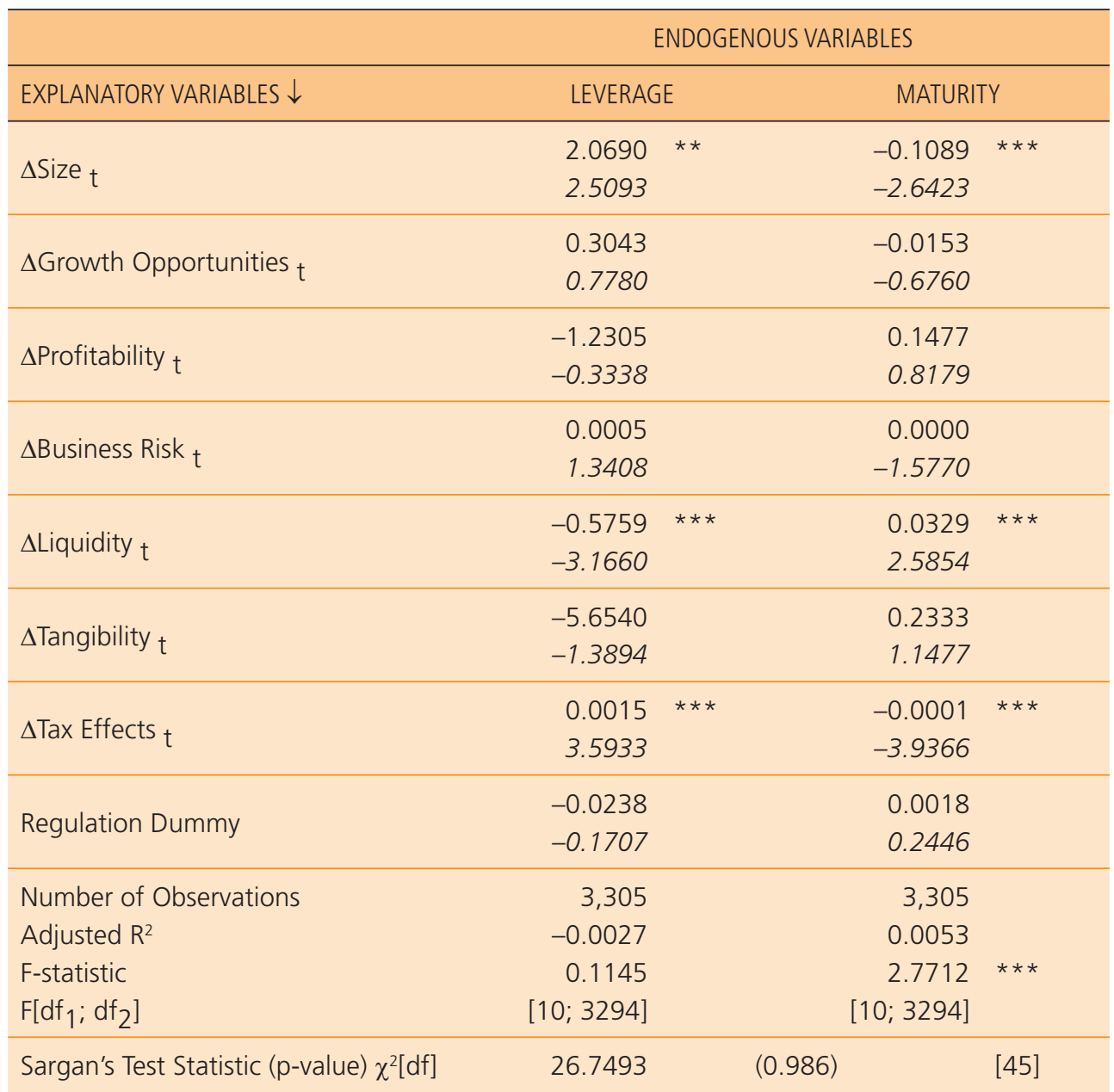

*First-differences model so that idiosyncratic firm-effects constant through time are eliminated. The model is estimated by Generalized Method of Moments (GMM) using as instruments first order lagged values of the levels of explanatory variables, industry dummies, country dummies, and a constant. Estimation in the period I990-2002. "Latin America" refers to the pooling together of all firm-level data for Argentina, Brazil, Chile, Colombia, Mexico, Peru, and Venezuela. Endogenous Variables: Leverage $=$ Long-Term Book Liabilities $\div$ Book Equity; Maturity $=$ Long-Term Debt $\div$ Total Debt. Reported t-statistics are calculated using heteroskedasticity-robust standard errors (White) and are also robust to autocorrelation (Bartlett Kernel). $t$-statistics in italic; degrees of freedom in (brackets); p-values in (square brackets).

$* *$ Significant at the $5 \%$ level.

**** Significant at the $\mathrm{i} \%$ level.

Source: Elaborated by the author. 
One important issue when estimating via GMM is to make sure that the instrument set is adequate. Table 5 reports the Sargan's test statistic for the null hypothesis that moment restrictions are orthogonal. Results cannot reject the restrictions. Therefore, we conclude that the instrument set is valid.

The first empirical result is that both specifications explain very poorly both the leverage and the maturity of the sample. The maturity equation performs slightly better though. Another interesting result is that dynamic effects are significant for the maturity but not for the leverage equation. This indicates that firms face adjustment costs, albeit moderate, in the debt maturity decision, but not as much in the capital structure decision.

The result of most interest is the relationship between leverage and maturity as endogenous variables. Both are significantly positive determinants of each other in the Latin American sample. This finding indicates that these policy variables are likely complements instead of substitutes, contradicting the theoretical prediction suggested by Barclay, Marx, and Smith Jr. (2003). One possible explanation for this result is that, given the particular institutional and economic environments of Latin America, bigger firms in these markets (of which the listed companies of our sample are an example) obtain a financial advantage that allows them to use financing alternatives in their favor, thus reinforcing each other.

Regarding the remaining explanatory variables, Size is found significant and positive in the leverage equation and significantly negative in the maturity equation. Liquidity, on the other hand, as a significantly negative effect on leverage but a positive one in maturity (i.e., more liquid firms choose less and longer debt). Tax Effects are significantly positive in leverage and negative in maturity, indicating that more heavily taxed firms choose a higher level of indebtedness and shorter maturity, which is in line with the static-trade-off explanation of capital structure. The remaining variables are not significant. It is worth to underscore that the two variables pointed out by Barclay, Marx, and Smith Jr. (2003) as the major theoretical determinants of the joint decision, Growth Opportunities and the Regulation dummy, are not significant in any equation and sample.

\subsection{SENSITIVITY ANALYSES}

One question that emerges from the cross-country approach chosen in this paper is whether a single country may be driving the results. In order to check for the robustness of the findings, we apply Leamer's (1983) global sensitivity approach to the sample. We therefore re-estimate Eq. 6 dropping all observations of a given country at a time. We also check for the influence of a single year over 
the results by dropping all observations of a given year at a time, and that of a single industry by dropping all firms of an industry at a time. The results are reported in Figures I to 4.

Results of these sensitivity analyses in general support the robustness of the previous findings. Average coefficients for independent variables are similar to the results reported above, and so are the t-statistics. In particular, the significance is in general confirmed in the Leamer's histograms for those variables that are significant in the whole sample analysis presented in Table 5 (lagged leverage and lagged maturity, contemporaneous leverage and maturity, size, liquidity, and tax effects).

We therefore conclude that results reported in this paper are robust to the choice of countries, period, and industries covered.

\section{FIGURE I}

\section{GLOBAL SENSITIVITY ANALYSIS FOR LEVERAGE EQUATION IN LATIN AMERICA (COEFFICIENTS)}
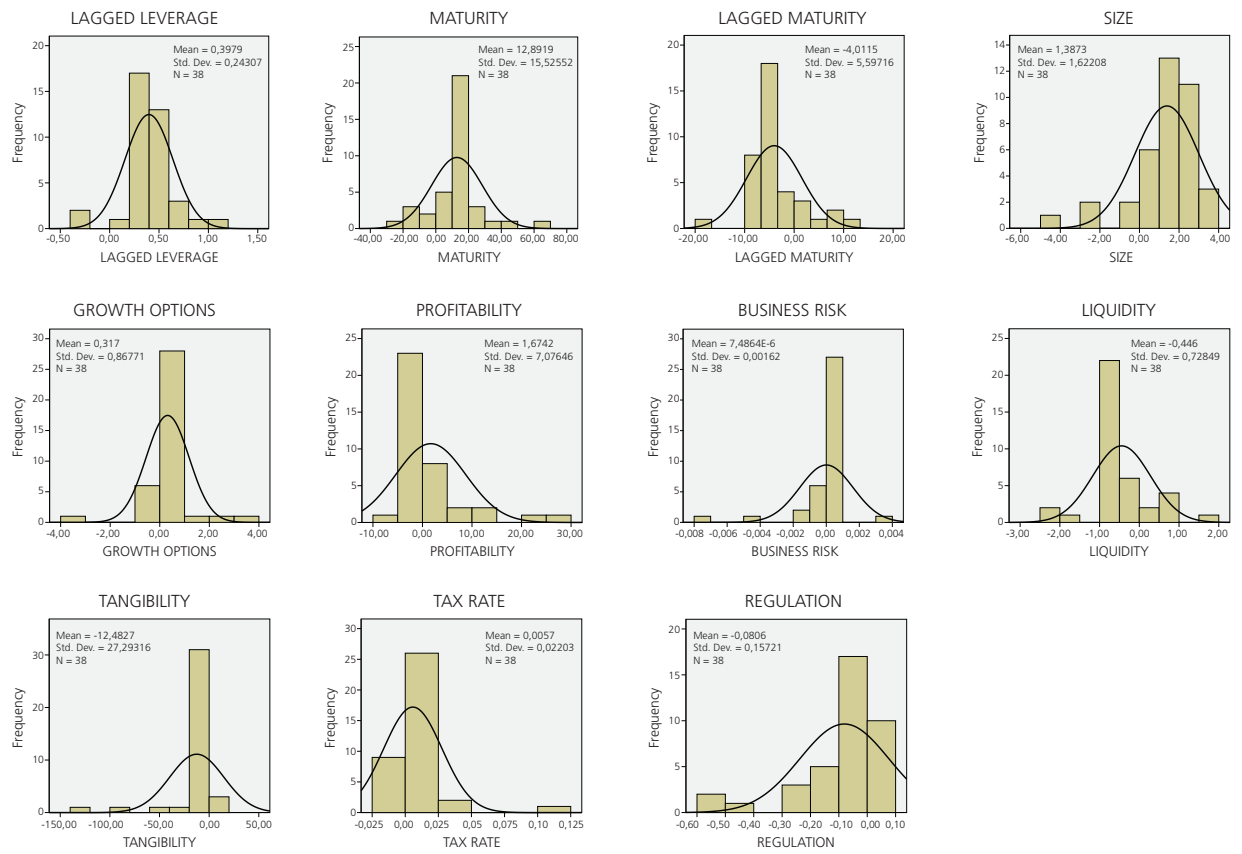

Source: Elaborated by the author. 


\section{FIGURE 2}

\section{GLOBAL SENSITIVITY ANALYSIS FOR MATURITY EQUATION} IN LATIN AMERICA (COEFFICIENTS)
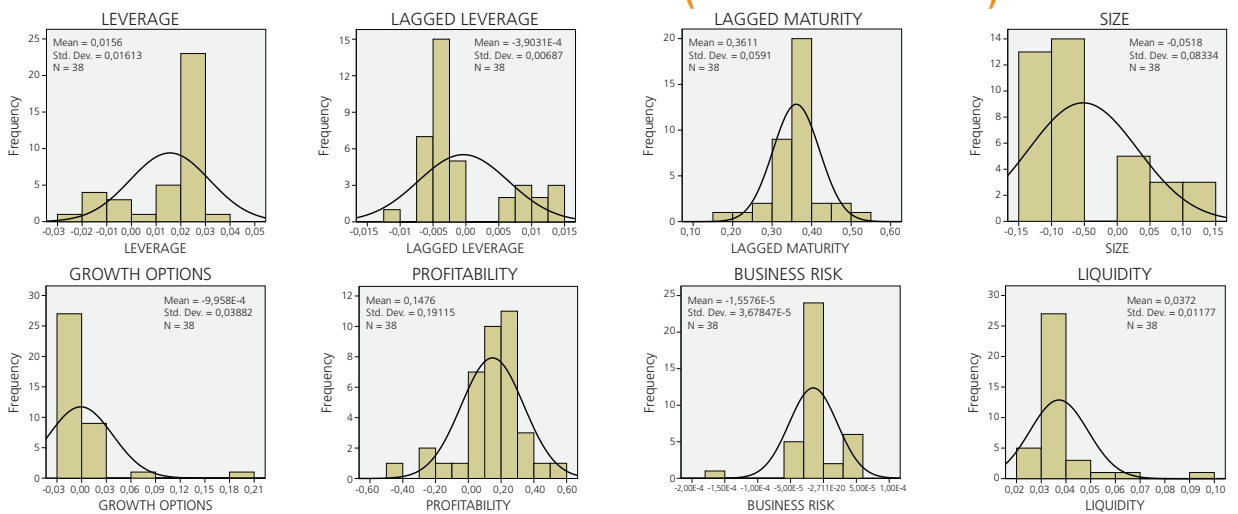

PROFITABILITY

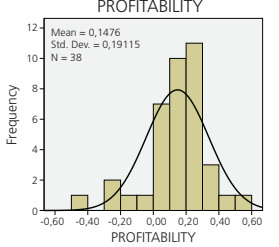

BUSINESS RISK

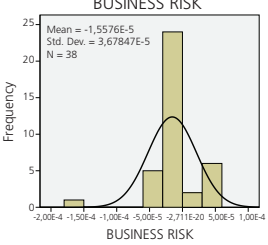

LIQUIDITY
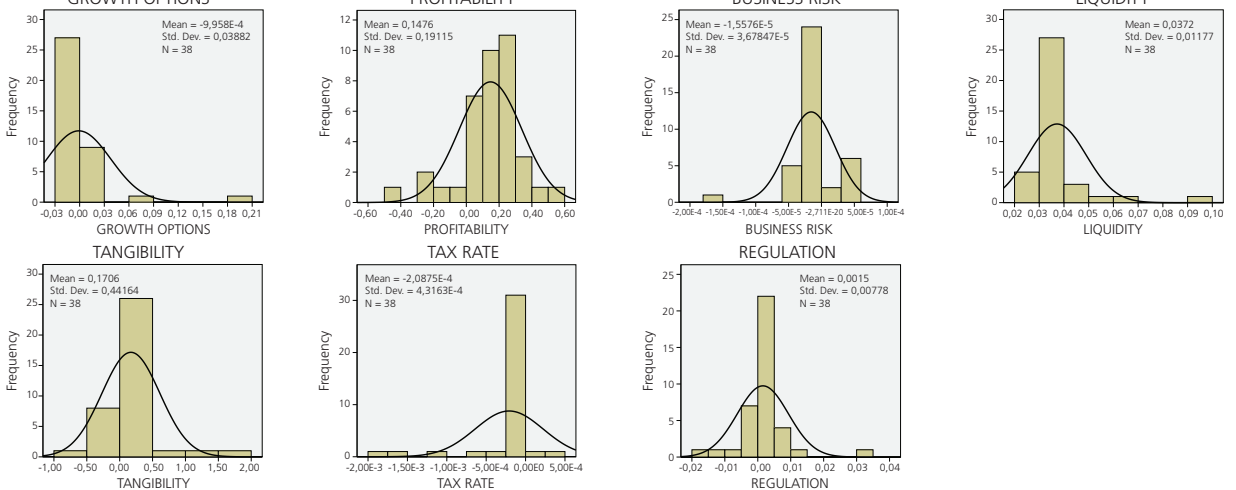

Source: Elaborated by the author.

\section{FIGURE 3}

GLOBAL SENSITIVITY ANALYSIS FOR LEVERAGE EQUATION IN

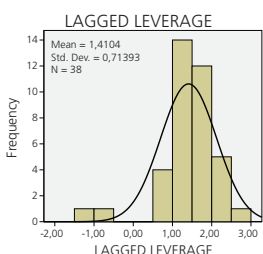
LATIN AMERICA (T-STATISTICS)
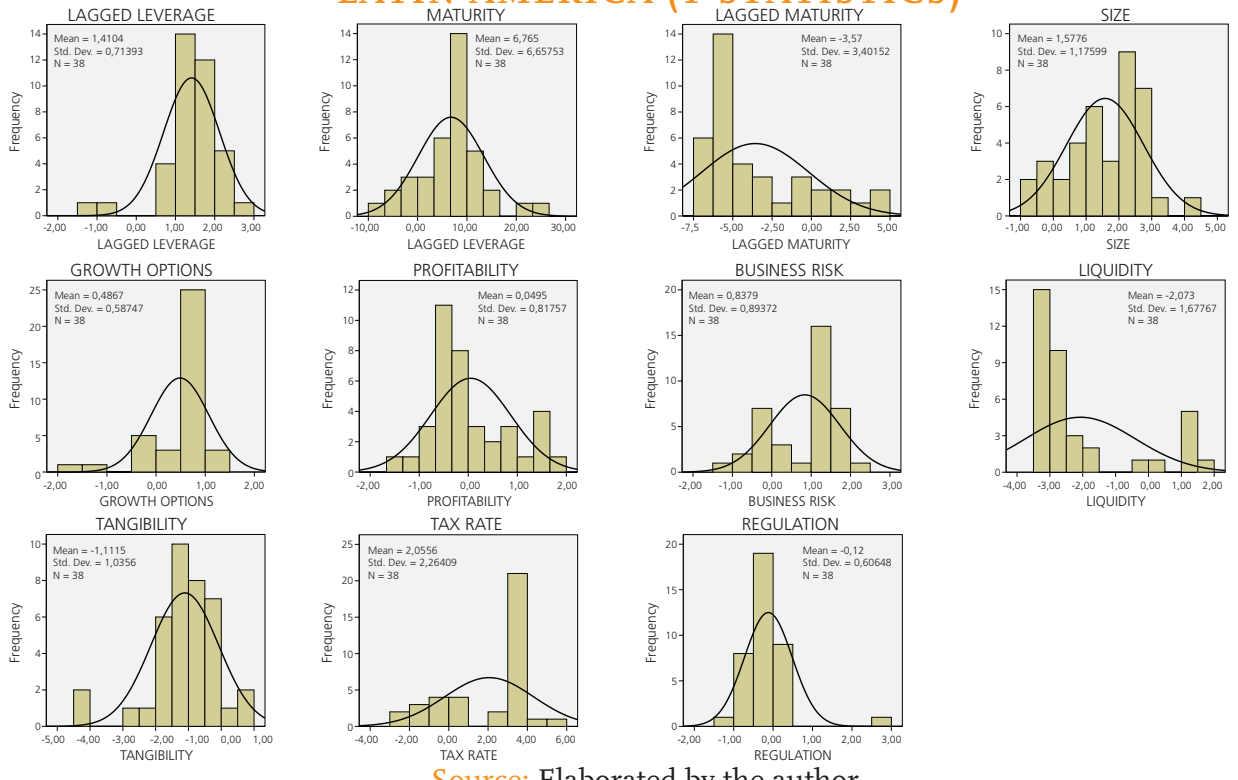


\section{FIGURE 4}

GLOBAL SENSITIVITY ANALYSIS FOR MATURITY EQUATION IN LATIN AMERICA (T-STATISTICS)
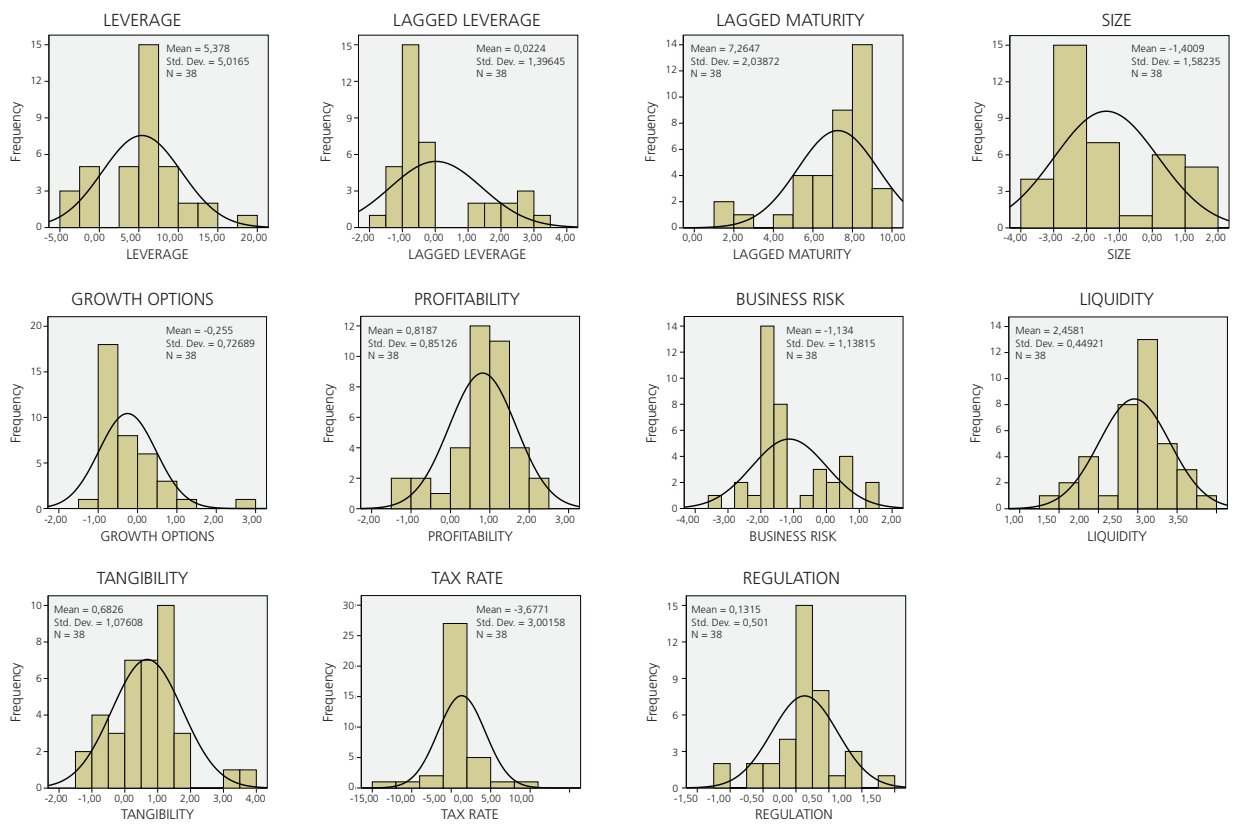

Source: Elaborated by the author.

\section{CONCLUSIONS}

The aim of this paper is to investigate the choice between debt and equity simultaneously with the decision between short-and long-term debt for a large sample of firms from Latin America. To address this question, a sample of 986 non-financial firms from Latin America over a I4-year period is analyzed.

The empirical results support three main findings. First, cross-effects between capital structure and debt maturity suggest that these policy variables are likely complements in Latin America. Second, there is a substantial dynamic component in the determination of debt maturity, a factor that has been overlooked by previous research. Finally, firms face moderate adjustment costs towards their optimal maturity.

In spite of the results, the quality of measurement of the variables should be looked with some caution. As noted, accounting standards, financial market depth, and the degree of supervision on financial reporting may vary largely across countries which may harm the comparability of the results. Also, some 
truly exogenous variables are not available for this sample, and the exogeneity of other variables may be weak.

Some additional issues should be addressed to develop this study. First, the different privatization policies followed in these countries, which give rise to different corporate governance types. Second, the degree of development of the financial markets and the importance of the banking sector. Finally, an extension to small- and medium-sized unlisted firms, which differ with respect to agency and asymmetric information problems from large listed counterparts, giving rise to different financing sources.

\section{REFERENCES}

AMIR, R. Supermodularity and complementarity in economics: an elementary survey. Southern Economic Journal, Chattanooga, v. 7I, n. 3, p. 636-660, 2005.

ANDERSON, T. W.; HSIAO, C. Estimation of dynamic models with error components. Journal of the American Statistical Association, Alexandria, v. 76, n. 375, p. 598-606, I98I.

ANTONIOU, A.; GUNEY, Y.; PAUDYAL, K. The determinants of debt maturity structure: evidence from France, Germany and the UK. European Financial Management, Bognor Regis, v. I2, n. 2, p. I6I-I94, 2006.

ARELLANO, M. A note on the Anderson-Hsiao estimator for panel data. Economics Letters, Amsterdam, v. 3I, n. 4, p. 337-34I, I989.

ARELLANO, M.; BOND, S. R. Some tests of specification for panel data: Monte Carlo evidence and an application to employment equations. Review of Economic Studies, London, v. 58 , n. 2, p. 277-297, I99I.

BALTAGI, B. H. Econometric analysis of panel data. Chichester: John Wiley \& Sons, I995.

BARCLAY, M. J.; MARX, L. M.; SMITH JR., C. W. The joint determination of leverage and maturity. Journal of Corporate Finance, Amsterdam, v. 9, n. I, p. I49-167, 2003.

DEMIRGÜÇ-KUNT, A.; MAKSIMOVIC, V. Institutions, financial markets, and firm debt maturity. Journal of Financial Economics, Rochester, v. 54, n. 3, p. 295-336, I999.

ECONOMÁTICA. Economática Pro, Versión 2003.aug.I8, São Paulo: Economática, 2003.

EROL, T. Strategic debt with diverse maturity in developing countries: industry-level evidence from Turkish Manufacturing. Emerging Markets Finance and Trade, Birmingham, v. 40, n. 5, p. 5-24, 2004 .

FAN, J. P. H.; TITMAN, S.; TWITE, G. An international comparison of capital structure and debt maturity choices. Social Sciences Research Network Working Paper, n. 423483, 50 p. Disponível em: $<$ http://ssrn.com/abstract=423483>. Accesso em: 2I out. 2008.

HALL, B. H.; CUMMINS, C. TSP version 4.4 user's guide. Palo Alto: TSP International, I997.

HANSEN, L. P. Large sample properties of generalized method of moments estimators. Econometrica, Princeton, v. 50, n. 4, p. 1029-1054, I982.

HSIAO, C. Analysis of panel data. Cambridge: Cambridge University Press, I986. 
LEAMER, E. E. Sensitivity analyses would help. American Economic Review, Nashville, v. 75, n. 3, p. 308-313, I983.

MILGROM, P.; SHANNON, C. Monotone comparative statics. Econometrica, Princeton, v. 62, n. I, p. I57-I80, I994.

MILLER, M. H. Debt and taxes. Journal of Finance, Berkeley, v. 32, n. 2, p. 26I-275, I977.

MILLER, M. H.; MODIGLIANI, F. Dividend policy, growth and the valuation of shares. Journal of Business, Chicago, v. 34, n. 4, p. 4II-433, I96I.

MODIGLIANI, F.; MILLER, M. H. The cost of capital, corporation finance and the theory of investment. American Economic Review, Nashville, v. 48, n. 3, p. 26I-297, I958.

Corporate income taxes and the cost of capital: a correction. American Economic Review, Nashville, v. 53, n. 3, p. 433-443, I963.

ROSS, S. A.; WESTERFIELD, R. W.; JAFFE, J. Corporate finance. 6. ed. New York: McGraw-Hill, 2002.

STIGLITZ, J. E. On the irrelevance of corporate financial policy. American Economic Review, Nashville, v. 64, n. 6, p. 85i-866, I974.

WHITE, H. A Heteroskedasticity-consistent covariance matrix estimator and a direct test for heteroskedasticity. Econometrica, Princeton, v. 48, n. 4, p. 8I7-838, I980. 